\title{
Contemporary Socialist Realism Within Indonesian Local Toss up Cards in the 1940s-1950s Era
}

\author{
Diesta Noor Shinta ${ }^{1, *}$ Trie Hartiti Retnowati ${ }^{1,}$ Hadjar Pamadhi ${ }^{1}$ \\ ${ }^{I}$ Art Education, Yogyakarta State University, Yogyakarta, Indonesia \\ *Corresponding author. Email: diestans15@gmail.com
}

\begin{abstract}
Local animated toss up cards were favorite animated cards during 1930s-2000s in Indonesia. Shadow puppet characters had inspired the production of these cards during 1940s and 1950s, specifically toss up cards featuring Petroek-Gareng characters acting as Dutch who embodied culture and custom of the Netherlands. At present, these local animated toss up cards have become rare and developed into collectibles. This study employed qualitative method by interpreting the characters visualized as colonizers (the bourgeois). The researcher analyzed the data from sources and documentation of toss up cards sourced from a number of books on the local animated toss up cards by Ibnu 'BENU' Wibi Winarko. This research aimed to review the local animated toss up cards from 1940s to 1950s as a form of contemporary artwork based on Danto's theory by viewing contemporary artwork in the following perspectives: (1) arts as the drive for transformation, (2) arts as the tool to understand culture, and (3) arts as carrying meaning in the social realism concept and revealing the reasons behind visualization of shadow puppet characters of Petroek-Gareng as Dutch with the other shadow puppet characters acting as natives to represent the issues arising at the time in the toss up cards.
\end{abstract}

Keywords: Toss up cards, Socialist Realism, Contemporary Art

\section{INTRODUCTION}

The local animated toss-up cards are a type of game cards with sizes ranging from $4 \mathrm{~cm} \times 3 \mathrm{~cm}$ to $4 \mathrm{~cm} \times 4 \mathrm{~cm}$. These cards appeared during the 1930s and became a form of entertainment for primary school kids due to their colorful designs. In Indonesian these cards are called 'Gambar Umbul' and the word 'umbul' is a Javanese word meaning 'toss up' because the cards are played by tossing them up. The winner of the game is the one whose card is facing upward upon falling on the ground, while the owner of the card facing down would lose [9].

At present, these local toss up cards have lost their fame as digital games have become more attractive to play, which is in stark contrast with the height of their fame in those past years when technology was not advanced and interactive. This includes the development of information technology which has enabled people to play collectively online from distance. This development has led collectors to collect these rare cards which have become antique. For some collectors, these cards have made them nostalgic about their childhood when they played toss up game and offered a kind of satisfaction when they obtain cards with appealing illustrations.

Indonesian native culture had become the source of inspiration of the toss up cards artists at the end of 1920 s, especially the puppet shadow characters from the island of Java. For business purposes, both colonial Dutch and local cigarette producers used these cards purely to boost sales. The other reason for the use of these local toss up cards was to introduce Indonesian culture overseas [10]. In the 1970s, popular movie clips, cartoon movies, and comic books were the inspiration for the toss up cards artists. The latter development has caused local toss up cards to lose their fans as the cards become monotonous and unattractive, specifically for children who are generally fond of new and more interesting objects [10].

In the development of contemporary fine arts, objects which previously served for commercial purposes, can be categorized into artwork. A range of examples are present, for instance, urinoir, Michael Duchamp's work in the beginning of contemporary arts, and Andy Warhol's collection of wood boxes, Brillo. Considering the points being made here, the 
author aims to discuss how a type of local animated toss up cards illustration can be perceived as a form of contemporary arts by referring to Danto's philosophic art theory of social realism concept. Through this study, the author would like to present an alternative view for the values of local animated toss up cards as contemporary artwork.

\section{LITERATURE REVIEW}

\subsection{The Concept of Socialist Realism}

The socialist realism movement represents events and issues existing in society, especially those happening to commoners. Maxim Gorky, a prominent writer, introduced this movement [7].

$\mathrm{N}$ Tan in Trisusanto [7] argues that social realism conception which was approved in the first Russian Writers' Congress contains:

"Socialist realism refers to the basic method and critique of Russian literature which require that the author provide a faithful, truthful and historically concrete presentation of the reality in its revolutionary development. Socialist realism must integrate true an concrete allegiance based on history in this artistic presentation with the aim to provide ideological education and training to the labour in the spirit of socialism."

In his book The Cambridge History of Russian Literature in Trisusanto [7] Charles A. Moser explains socialist realism as a similar idea to that of Maxim Gorky's realism, namely, realism describes the events that are happening as well as those that should happen in the society so that socialism can be achieved. Gorky's view clearly points to realism literature not only to improve the people's prosperity today, but also to provide some imagery of an ideal society in the eye of socialism. Therefore, Gorky's idea of realism belongs to socialist realism.

There was an Indonesian writer who followed the movement of socialist realism, namely Pramoedya Ananta Toer who was also known as a world figure in the world of literature. Pramoedya, as a member of the PKI (Indonesian Communist Party), had the aesthetic principle of the art of Marxism in choosing issues that exist in the surrounding community to be presented in his literary works, one of which is Stories of Blora. H.B. Yassin mentions in the foreword to the Stories of Blora that Pramoedya had a spirit of humanism and compassion arguing,

"Pram does not burden his sympathy for any ideology except for humanity."

Therefore, for Pramoedya, he highlighted the problems that arose in society at that time as the main theme of his work, Stories in Blora, such as the consequences of poverty in the Blora area where he lived, and where people were suffering due to colonialism, disgraceful actions during colonialism, and so on [1].

Pramoedya Ananta Toer was also involved in the Lekra (People's Cultural Institute) under the auspices of the PKI. "Popular Realism", which was the term for socialist realism applied by Lekra [1].

Arbuckle in Junaedi [2] argues that even though Communism in Indonesia no longer exists, Taring Padi, an organization which was founded in 1988, still maintains a popular understanding of art. Taring Padi has some concerns about a government that prioritizes economic interests which results in art only becoming a cultural product as a tool to obtain revenues in the form of foreign exchange, resulting in alienation or distancing of understanding of art between artists and society in general.

\subsection{Contemporary Art}

In the Indonesian dictionary composed by Baudu and Zain in Saidi [5], there are three lexical meanings of the word contemporary namely (1) contemporaneous, contemporaries; (2) at the same time, simultaneous; (3) present, current. Badudu provides an example for this: "contemporary art cannot last long". Likewise, in the book of Diksi Rupa, Mikke Susanto [6] reveals that the word contemporary itself means a contemporary era in which the author or observer lives.

There is an emphasis on contemporary art that it is not a term that refers to a genre or artistic style, but an artistic activity that is considered current by observers who live during the concerned period. Arthur C. Danto proposes that the definition of contemporary art in the context of "contemporary style" is not yet formed. He further argues that the term contemporary art could be replaced by postmodern art. According to Danto himself, the term contemporary in contemporary art does not only provide an impression of temporal sense, but also art that is produced by procedures that have never been used before [5].

In response to the aesthetics deviation of contemporary arts, as cited in Kenyowati E., Danto in his book "The Abuse of Beauty Aesthetics and the Concept of Art" [3] discussed the deviations in the beauty, aesthetics, and concept of art. He opens his discussion by referring to Andy Warhol's work on Brillo Box (1964) [8]. This carton box has been used as packaging for aluminum cleaning soap from USA designed by James Harvey. Andy Warhol presents Brillo box as artwork in the form of wooden box (plywood) with silkscreen ink. Andy Warhol used the same design and popular art design, and the work has been displayed numerous times in galleries and exhibitions. In Danto's Transfiguration of the Commonplace, it is explained that an object can be an artwork because of an external factor named the art 
world, that is the relevant historical and theoretical contexts which make the object to be a form of artwork and in which the artwork exists.

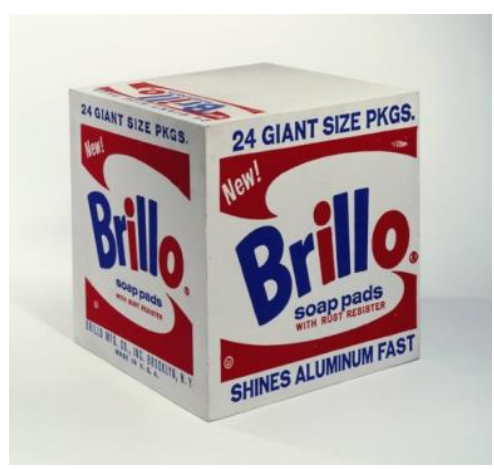

Figure 1 Brillo Box, Andy Warhol (1964) [8]

Traditionally, beauty is inseparable from that understanding, therefore Danto views this as the factor which makes art become special, highly valued and grand. However, in Warhol's Brillo box, the traditional definition of art no longer applies. In the end, the contemporary definition over takes the traditional view because an artwork is not always beautiful [3].

Danto in Kenyowati E [3] categorizes artwork beauty into two, that is internal and external beauty. Robert Motherwell's painting "Elegies to the Spannish Republic" for example, is a piece of artwork which possesses internal beauty. In internal beauty, there is some feelings besides beauty such as being sickening, erotic, and sublime. Elegies to the Spannish by Robert Motherwell is a symbolic representation of "lamentation or funeral songs" after the Spannish Civil War. Motherwell connects this work and the testicles of a dead bull in a Spannish bullfight and describes his work as his own urgency, that the terrible death cannot be forgotten and those images are general metaphors of the contrast between life and death. In Andy Warhol's [8] discussion of Brillo Box, Danto view the object as having external beauty. He further explains that people choose daily goods not only because of their functions but also because of the attractive design. As it is now, when people are presented with two products having the same function but one of them has more appealing packaging design, the product with the more appealing design will be preferred.

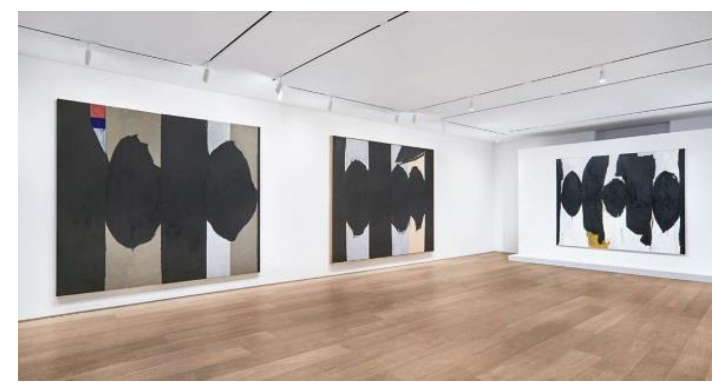

Figure 1 Elegies to The Spanish, Robert Motherwell (1965-1967) [4]
Danto in Kenyowati E [3] presents three ways of viewing an object as a piece of artwork, namely: (1) art as transformative drive; (2) art as a tool to understand culture; and (3) art as a meaningful work.

Art as transformative drive can be explained in the case of Maya Lin's work, the Vietnam Veteran's Memorial of which beauty lies on the positive effect on those who come to mourn or appreciate the object as an artwork. In Danto's view, art is not a purpose anymore, but it is a tool to understand culture in which art is part of it, and then he relates art from a certain culture to humanity in a broader term. Art as artwork is always meaningful through the medium or object that presents it. The meaning of an art work comes from the ideas presented or expressed non-verbally.

\section{RESEARCH METHOD}

This research employed a qualitative design with a descriptive method. The data in this study comprises documentation of local toss up cards in the end of $1940 \mathrm{~s}$ to $1950 \mathrm{~s}$. The author was the instrument of research as human instrument. For data analysis technique, the researcher utilized Miles and Huberman's descriptive analysis technique which consists of data reduction, data display, and conclusion drawing.

\section{FINDINGS}

In the study, the author has analyzed the data and found the following findings. First, the author has found socialist realism concept in the Petroek-Gareng toss up cards. This is the main focus of an artwork, especially in contemporary art, and through Danto's views on perceiving contemporary artwork so that Petroek- Gareng toss up cards can be viewed as contemporary artwork.

\section{DISCUSSION}

Based on the findings, one of the most phenomenal toss up cards in circulation was Petroek-Gareng toss up cards which can be viewed as contemporary artwork because these cards represent issues in the society through socialist realism concept. By observing at the period, the era during 1040 s to 1950 s was the period of Dutch colonization in Indonesia.

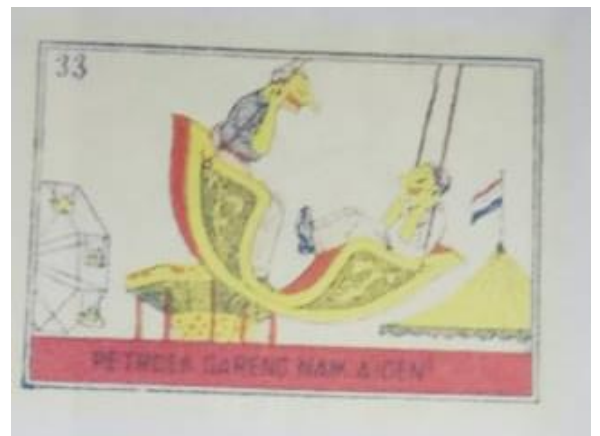


Figure 2 Petroek Gareng Naik Ajoen2. (Petroek on a swing) [9]

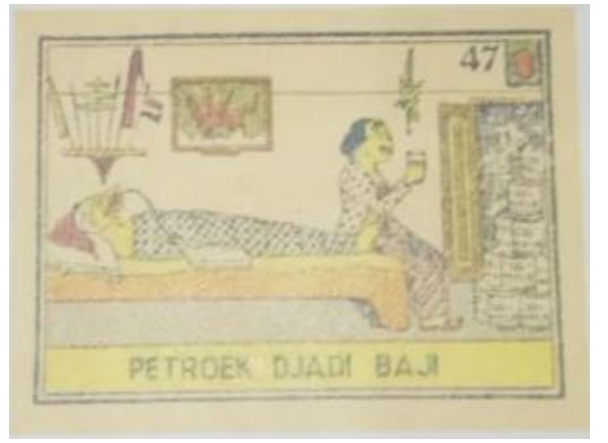

Figure 3 Petroek Djadi Baji (Petroek becomes drunk). [9]

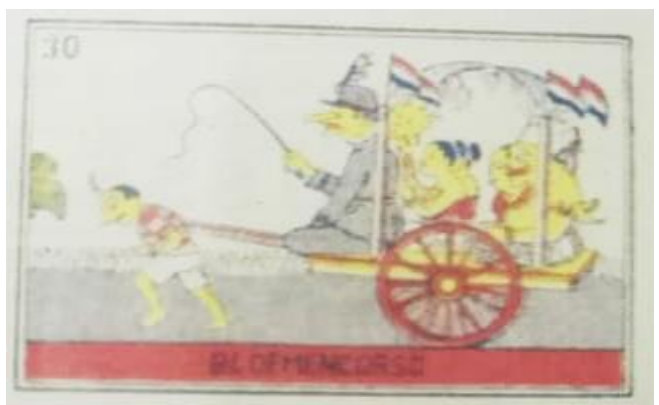

Figure 4 Bloemencorso (At a local flower festival) [9]

The description of the situation in the society during the period is represented by the background illustrations of the toss up cards such as the corresponding Dutch flag and culture at that time. The situation of the lower class people can be seen as inferior compared to the middle class (white collar workers) and the Dutch army officers (the bourgeois) in contrast to the simple life led at that time. There are political elements as shown by the Dutch dominating authority and power, so to make them subtle, the entertaining, playful and humble Punakawan characters of the shadow puppets are used in the illustration because there was no happiness and prosperity especially for the lower class members of the colonized society.

Besides, the Petroek-Gareng toss up cards can be seen as contemporary artwork as seen in three different ways as proposed by Danto, of which the first one is art as transformative drive. The beauty of the PetroekGareng toss up cards as transformative drive can be observed in the people who appreciate the toss up cards as a card game for any part of the society and the comedy which represents the situation of the society during that period. Secondly, art as a tool to understand culture is also present in these toss up cards. The everyday life of the society serves as the inspiration for the modern actualization at that time, and also as media to spread news on the events in the city or new media of introduction from the urban areas to rural areas. While the characters illustrated in the cards come from
Javanese traditional shadow puppets characters, there are still modern touch such as bike riding and boxing.

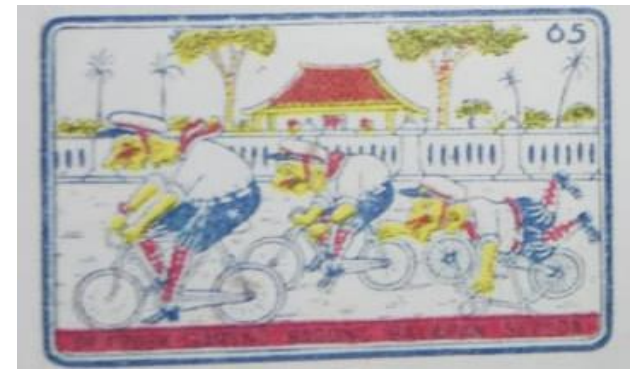

Figure 5 Petroek, Gareng, Bagong, Balapan Sepeda (Petroek, Gareng, Bagong in a bike race). [9]

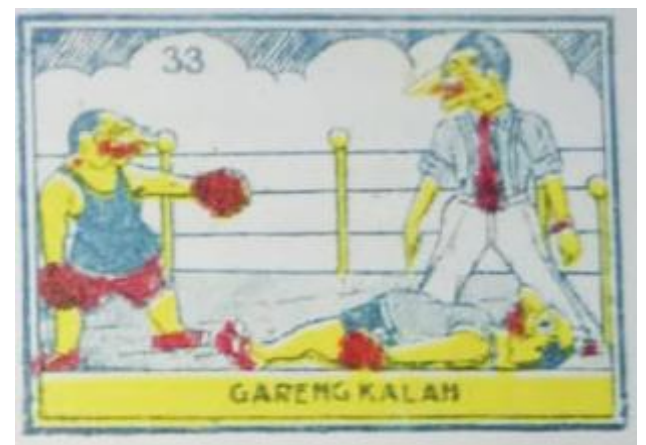

Figure 6 Gareng Kalah (Gareng is defeated in a boxing match) [9]

Lastly, Petroek-Gareng toss up cards as meaningful artwork is expressed through the illustrations. The meanings are expressed through the illustrations which represent comedy, culture, and everyday life of the Dutch colonial era in Indonesia. The beauty of PetroekGareng toss up cards can be viewed as having external beauty, as it is the case in Andy Warhol's work, the most sought after cards are the ones which are more attractive, as proven by the high production of the phenomenal toss up cards in the era.

\section{CONCLUSION}

The local toss up cards were gifts for products purchased at that time and became one of the favourite games, especially among children. The illustrations in the toss up cards were inspired by the popular events during the period. In the beginning of the local toss up cards production in Indonesia (1940-1950) as the authentic local toss up cards, some of the most preferred cards were Petroek-Gareng toss up cards. These toss up cards are perceived as possessing the values of contemporary art with socialist realism concept as the core issue and meaning as artwork, so that Petroek-Gareng toss up cards can be viewed as contemporary artwork. 


\section{REFERENCES}

[1] Ghazali, Syukur. Mengenal Wajah Indonesia melalui Penulis Realisme Sosialis Pramoedya Ananta Toer [Getting to know the face of Indonesia through the writer of socialist realism Pramoedya Ananta Toer]. Bahasa dan Seni (2007): 58-75.

[2] Junaedi, Deni. Benturan Estetis antara Liberalisme, Sosialisme, dan Islam [Aesthetic Clash between Liberalism, Socialism and Islam]. Jurnal Kawistara 2 (2012): 264-275.

[3] Kenyowati E, Embun. Problem Keindahan Dalam Seni Telaah Buku [The Problem Of Beauty In Arts Review] Arthur C. Danto the abuse of beauty 2003. Jurnal Dimensi 7.01 (2009).

[4] Motherwell, Robert. Robert Motherwell. Elegy to the Spanish Republic, 108. 1965-67 | MoMA. The Museum of Modern Art, 19AD, www.moma.org/collection/works/79007.

[5] Saidi, Acep Iwan, and Mega Sekti Dwi Astuti. Narasi Simbolik Seni Rupa Kontemporer Indonesia [Symbolic Narrative of Indonesian Contemporary Art]. Isac Book, 2008.

[6] Susanto, Mikke. Diksi rupa: kumpulan istilah seni rupa. Kanisius, 2002.

[7] Trisusanto, Asep. Realisme Sosialis dalam Tokoh dan Penokohan Novel "Kehidupan Seorang Manusia yang Tidak Berguna" Karya Maxim Gorky [Socialist Realism in the Characters and Characteristics of Maxim Gorky's "The Useless Life of a Human"]. 2012. Universitas Indonesia, Undergraduate thesis. Unpublished.

[8] Warhol, Andy. Brillo Box (Y1993-132). Princeton Art Museum, 1964, artmuseum.princeton.edu/collections/objects/33816

[9] Winarko, Ibnu Benu Wibi. Gambar Oemboel Indonesia. Ed.1 Yogyakarta: Gareng, 2010. Buku Teks.

[10] Winarko, Ibnu W. Gambar Oemboel Tjerita, 2018. Print. 